Research article

\title{
Ecological studies of mangroves species in Gulf of Khambhat, Gujarat
}

\author{
Vandna Devi and Bhawana Pathak* \\ School of Environment and Sustainable Development, Central University of Gujarat, Gandhinagar, India \\ *Corresponding Author: bhawana.pathak@cug.ac.in \\ [Accepted: 28 September 2016]
}

\begin{abstract}
Mangrove forests are of utmost importance due to their role in preventing extreme weather events like tsunamis and cyclones etc. The present study aimed to observe the mangrove plant diversity and edaphic characteristics from Gulf of Khambhat, Gujarat. Ecological parameters and edaphic characteristics were studied for different sites i.e. Navsari, Surat and Bhavnagar. Avicennia marina was found as dominant species at all study sites. Plant species diversity shows increasing tendency with the decrease in plant density. Important Value Index, Shannon-Weaver diversity index and Simpson index of dominance of the mangrove species across the study area were also determined. The present study provides the baseline data of mangrove species and concludes the need of detail study for mangrove species in Gulf of Khambhat, Gujarat for conservation and management strategies.
\end{abstract}

Keywords: Mangrove plants - Avicennia marina - IVI - Plant density - Conservation.

[Cite as: Devi V \& Pathak B (2016) Ecological studies of mangroves species in Gulf of Khambhat, Gujarat. Tropical Plant Research 3(3): 536-542]

\section{INTRODUCTION}

Mangrove forest ecosystems are significant for the biodiversity, protection of coastal area from erosion and provision of protected nursery breading areas for marine fauna. Ecological study of any area or habitat helps to understand the inter-relationship of all biotic (plants, microbes, other organisms) and abiotic (temperature, moisture and soil etc.) components of environment. Globally mangrove forest cover around 1,46,500.00 $\mathrm{km}^{2}$ of coastline (Alongi 2008) while total mangrove cover India is about $4,662.56 \mathrm{~km}^{2}$. This represents $0.14 \%$ of the total geographical area of country and $3 \%$ of the global mangrove area. Mangroves are world's most productive ecosystems, found at the interface between land and sea in tropical and subtropical latitudes. Mangrove forests are only forest on earth where land, freshwater and sea mix together. These forests are specially adapted to high salinity, extreme tides, strong winds, high temperatures, low oxygen and muddy soil (Kathiresan 2010).

Gujarat is situated in the west coast of India which is surrounded by Arabian Sea. In maritime states of India; Gujarat has largest coastal area around $28,000 \mathrm{~km}^{2}$ or longest coast line around $1650 \mathrm{~km}$ supports variety of marine flora and fauna. The area under mangrove cover $\left(1058 \mathrm{~km}^{2}\right)$ along the Gujarat coast is the second largest block of tidal forest in India, next only to the Sunderbans $\left(2155 \mathrm{~km}^{2}\right)$ (MoEF 2013-14). This state has two gulfs out of three gulfs in India and the coastal area is spread from south Gujarat (high rainfall area about 2500 $\mathrm{mm}$ ) to north- west of Kachchh (low rain area about $250 \mathrm{~mm}$ only). Different range of tides, waves, cyclones and currents in the sea affect the physical as well as the biological conditions of the marine ecosystem whereas clear cutting, hydrological changes, oil spills and climate change are creating more pressure on mangrove forests sites (Blasco et al. 2001). In Gujarat $1103 \mathrm{~km}^{2}$ area is under mangrove which includes $175 \mathrm{~km}^{2}$ moderately dense mangroves (15.86\% of mangrove area of state), $928 \mathrm{~km}^{2}$ open mangrove $(84.13 \%)$. The present research study deals with the ecological status of mangrove species in Gulf of Khambhat, Gujarat.

\section{MATERIALS AND METHODS}

Study area

Gujarat state is situated on the west coast of India between $20^{\circ} 06^{\prime} \mathrm{N}$ to $24^{\circ} 42^{\prime} \mathrm{N}$ latitude and $68^{\circ} 10^{\prime} \mathrm{E}$ to $74^{\circ} 28^{\prime} \mathrm{E}$ longitude. It is bounded by the Arabian Sea on the west. Ghogha from Bhavnagar $\left(21^{\circ} 40^{\prime} \mathrm{N}, 7^{\circ} 17^{\prime}\right.$ E), Dumas from Surat $\left(21^{\circ} 4^{\prime} \mathrm{N}, 72^{\circ} 42^{\prime} \mathrm{E}\right)$, Dandi from Navsari $\left(20^{\circ} 55^{\prime} \mathrm{N}, 72^{\circ} 47^{\prime} \mathrm{E}\right)$, Dahej from Bharuch were selected from Gulf of Khambat (Cambey) are selected for the present research work (Fig. $1 \& 2$ ). 


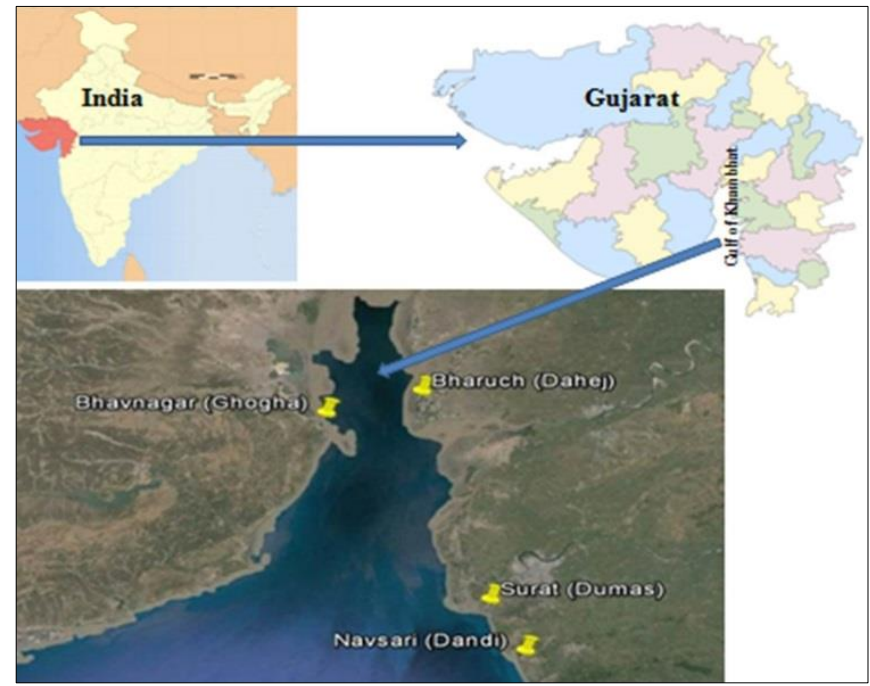

Figure 1. Aerial view of four selected sites (Source: Google Earth)
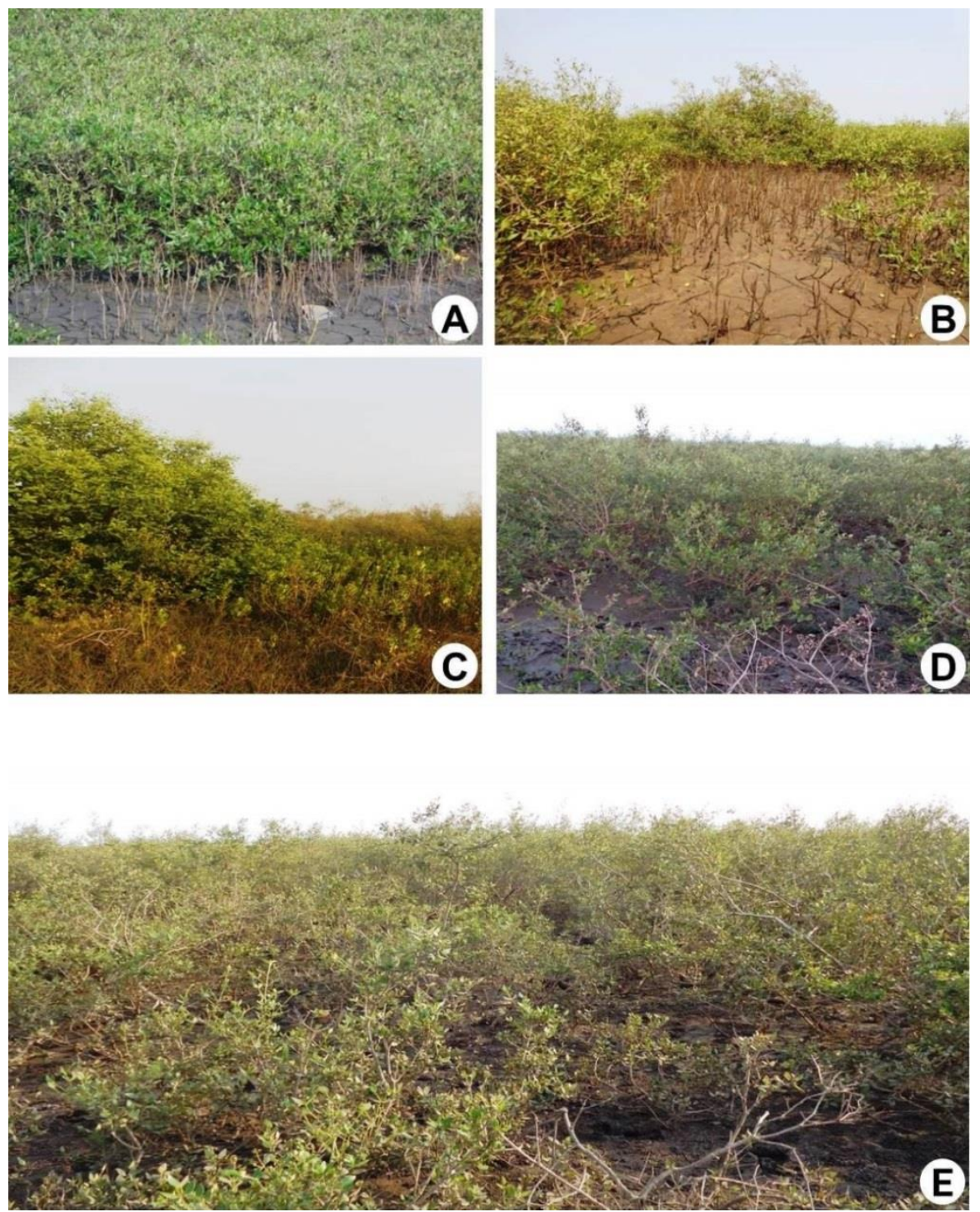

Figure 2. Habitat of mangrove vegetation: A \& B, Bhavnagar; C, Navsari, D, Bharuch; E, Surat.

\section{Field methods}

The mangrove vegetation study was carried out from selected sites during low tide. Quantification of mangrove vegetation at each site was done by quadrate method. 10 quadrates $(3 \times 3 \mathrm{~m})$ were laid randomly at 
each site and in each quadrate, total numbers of trees were counted; tree height and Girth at Breast Height (GBH) was measured for all trees. Quantity parameters like frequency, relative frequency, density, relative density, abundance, dominance, relative dominance, Important Value Index (IVI) was determined Curtis (1959). The distribution pattern of species was determined by ratio of abundance to frequency if the ratio is below 0.025 then it indicates regular distribution, between 0.025-0.050 indicates random distribution and when exceeds 0.050 indicates contagious distribution (Whitford 1949). Species diversity was determines by using Shannon index (H), Simpson's index of diversity (1-D) were calculated using standard methods (Shannon \& Weaver 1963, Simpson 1949, Kerkhoff 2010).

\section{Collection and authentication of plant samples}

Plant samples (leaves, flowers, stem, seeds and roots) were collected from selected sites for authentication and preparation of herbarium. Authentication and identification of collected plant samples was done with the help of Scientist, GEER foundation, Gujarat.

\section{Soil sampling and chemical analysis}

Soil samples were collected from $0-10 \mathrm{~cm}$ depths from each site during October and November of the year 2014. Five sets of samples were collected from each study site and mixed together to form a composite soil sample and from which three replicate samples were brought to the laboratory. Collected soil samples were air dried and sieved through a $2 \mathrm{~mm}$ mesh and was subjected to routine chemical analysis. Physicochemical characteristics of soil samples were determined using standard methods (APHA 1998). pH of soil was determined using method described by Black (1973). Total organic carbon was determined using method described by Walkey \& Black (1934).

\section{RESULTS}

Mangrove plant status

Table 1. Mangrove diversity of selected site of Gujarat.

\begin{tabular}{|c|c|c|c|c|c|c|c|}
\hline \multirow{2}{*}{\multicolumn{2}{|c|}{ Species Name }} & \multirow{2}{*}{$\begin{array}{l}\text { Vernacular } \\
\text { name }\end{array}$} & \multirow{2}{*}{ Family } & \multicolumn{4}{|c|}{ Status in various sites } \\
\hline & & & & Bhavnagar & Surat & Navsari & $\overline{\text { Bharuch }}$ \\
\hline \multirow{4}{*}{ 总 } & $\begin{array}{l}\text { Avicennia marina (Forsk.) Vierh } \\
\text { var. acutissima Mold. }\end{array}$ & Tivar, Tavarian & Avicenniaceae & + & + & + & + \\
\hline & Bruguiera gymnorhiza (L) Lam & Tavar & Rhizophoraceae & - & - & + & - \\
\hline & Sonneratia apetala Buch.-Ham & Motitavar & Lythraceae & - & + & + & - \\
\hline & Acanthus illicifolius & Kantaliyo & Acanthaceae & - & - & + & - \\
\hline \multirow{4}{*}{ 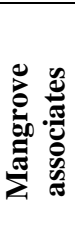 } & Ipomoea pes-carpae (L.) Sw. & Maryada-vel & Convolvulaceae & - & - & + & - \\
\hline & Sesuvium portulacastrum (L.) L. & Shore purslane & Aizoaceae & + & + & + & - \\
\hline & Salvadora persica $\mathrm{L}$. & Toothbrush tree & Salvadoraceae & - & + & - & - \\
\hline & Suaeda sp. & Seepweeds & Amaranthaceae & - & + & - & - \\
\hline
\end{tabular}

Note: + , indicates presence; - indicates absence.

The patterns of mangroves and associated species distribution in selected study area depict little variation in the species composition (Table 1). At Bhavnagar a total of 886 plants representing two species were identified within $90 \mathrm{~m}^{2}$ area survey. Avicennia marina (Forsk.) Vierh (Avicenniaceae) showed the highest density (87.5 plants $/ 90 \mathrm{~m}^{2}$ ) with $83.33 \%$ relative frequency $99.99 \%$ relative dominance and 282.09 important value index. Other species recorded with their ecological parameters is presented in table 2. Only two species (Avicennia marina and Sonneratia apetala Buch.-Ham.) were found at Surat site. The maximum number of species was recorded at Navsari site such as Avicennia marina, Sonneratia apetala, Bruguiera gymnorhiza (L.) Lam., and Acanthus ilicifolius L. (Fig. 3). Only one species (Avicennia marina) was recorded at Bharuch site.

Avicennia marina has been found common in all selected sites exhibiting maximum density at Bhavnagar $\left(87.5\right.$ plants $\left./ 90 \mathrm{~m}^{2}\right) \cdot$ Among all species the mean height was maximum of Sonneratia apetala $(230.86 \mathrm{~cm})$ followed by Avicennia marina $(127.28 \mathrm{~cm})$ and Bruguiera gymnorhiza $(109.82 \mathrm{~cm})$. Avicennia marina is dominating species at all selected sites with higher important value index at all sites. In general the distribution pattern of all species was contagiously distributed at all study sites except Sonneratia apetala, which showed random pattern of distribution at Surat and Navsari site. The Shannon-Weaver diversity index and Simpson 

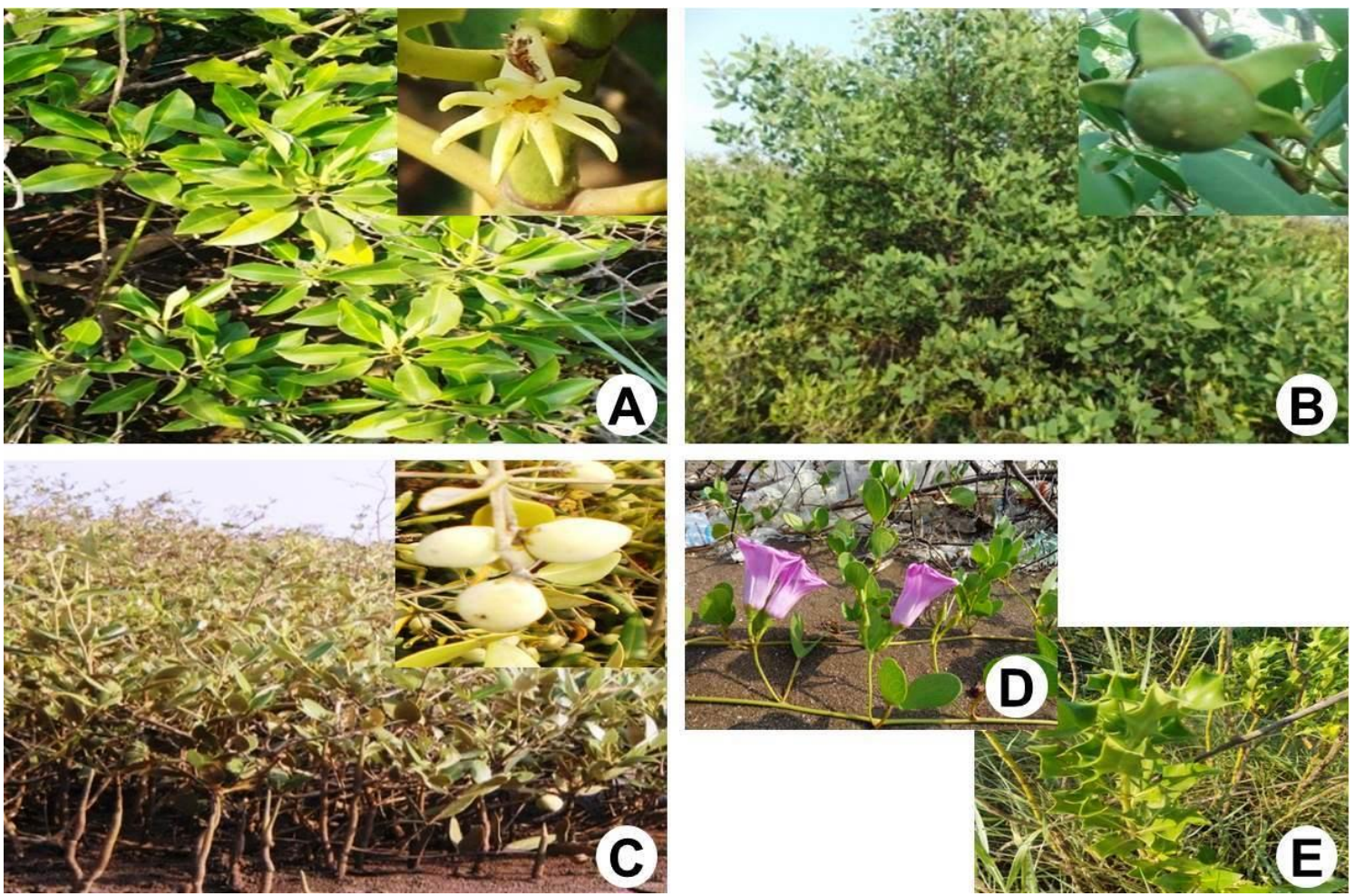

Figure 3. Some mangrove plants: A, Bruguiera gymnorhiza (L.) Lam.; B, Sonneratia apetala Buch.-Ham.; C, Avicennia marina (Forsk.) Vierh; D, Ipomoea pes-caprae (L.) R.Br.; E, Acanthus illicifolius L.

index of dominance was analyzed for dominance and species diversity (Shannon \& Weaver 1963, Simpson 1949). The Shannon-Weaver index showed highest diversity at Navsari site (1.20) followed by Surat $(0.20)$, Bhavnagar (0.07) whereas Simpson index of diversity (1-D) was higher in Navsari (0.66) followed by Surat (0.09), Bhavnagar (0.03) and the value of this index ranges between 0 and 1 , the greater the value, the greater the plant diversity. Result shows that Navsari site have been found with more diversity than other sites (Table 3 \& 4).

Table 2. Vegetation characteristics of different selected sites.

\begin{tabular}{|c|c|c|c|c|c|c|c|c|c|c|c|}
\hline \multicolumn{12}{|c|}{ Site 1 Bhavnagar } \\
\hline & 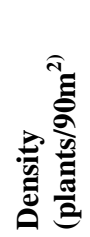 & 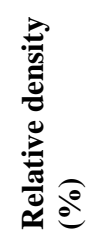 & 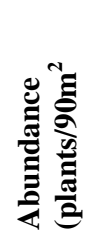 & 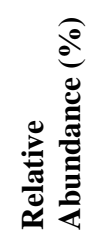 & 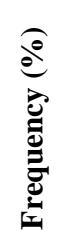 & 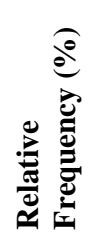 & 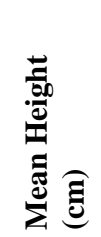 & 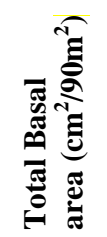 & 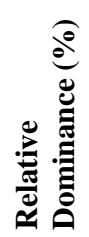 & 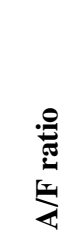 & 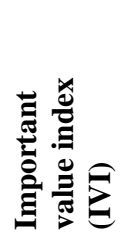 \\
\hline Avicennia marina & 87.5 & 98.76 & 87.5 & 94.09 & 100 & 83.33 & 71.68 & 471.59 & 99.99 & 0.88 & 282.09 \\
\hline Sesuvium portulacastrum & 1.1 & 1.24 & 5.5 & 5.914 & 20 & 16.66 & 3.30 & 0.006 & 0.001 & 0.28 & 17.91 \\
\hline \multicolumn{12}{|c|}{ Site 2 Surat } \\
\hline Avicennia marina & 13.7 & 95.14 & 13.7 & 88.67 & 100 & 71.43 & 86.87 & 61.63 & 96.83 & 0.13 & 263.39 \\
\hline Sonneratia apetala & 0.7 & 4.86 & 1.75 & 11.32 & 40 & 28.57 & 77.01 & 2.02 & 3.17 & 0.04 & 36.60 \\
\hline \multicolumn{12}{|c|}{ Site 3 Navsari } \\
\hline Avicennia marina & 14.9 & 43.44 & 14.9 & 40.27 & 100 & 27.03 & 127.28 & 122.39 & 44.74 & 0.15 & 115.21 \\
\hline Bruguiera gymnorhiza & 3.9 & 11.37 & 4.88 & 13.18 & 80 & 21.62 & 109.82 & 27.56 & 10.07 & 0.06 & 43.07 \\
\hline Sonneratia apetala & 3.1 & 9.04 & 3.44 & 9.31 & 90 & 24.32 & 230.86 & 119.63 & 43.73 & 0.04 & 77.09 \\
\hline Acanthus illicifolius & 12.4 & 36.15 & 13.77 & 37.24 & 100 & 27.03 & 63.75 & - & - & 0.14 & - \\
\hline \multicolumn{12}{|c|}{ Site 4 Bharuch } \\
\hline Avicennia marina & 18.5 & 100 & 18.5 & 100 & 100 & 100 & 114.6 & 43.09 & 100 & 0.185 & 300 \\
\hline
\end{tabular}

Table 3. Diversity indexes of selected mangrove sites.

\begin{tabular}{llll}
\hline Diversity indexes & Bhavnagar & Surat & Navsari \\
\hline Shannon-Weaver Index (H) & 0.07 & 0.20 & 1.20 \\
Simpson index of Diversity (1-D) & 0.03 & 0.09 & 0.66 \\
\hline
\end{tabular}

Note: At Bharuch site only single species Avicennia marina was recorded in selected sampling area. 
Table 4. Species diversity of different mangrove sites.

\begin{tabular}{|c|c|c|c|c|}
\hline Sites & Bhavnagar & Surat & Navsari & Bharuch \\
\hline \multirow{6}{*}{ 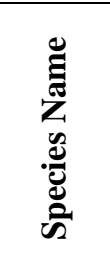 } & Avicennia marina & Avicennia marina & Avicennia marina & Avicennia marina \\
\hline & Sesuvium portulacastrum & Sonneratia apetala & Sonneratia apetala & \\
\hline & & Salvadora persica & Bruguiera gymnorhiza & \\
\hline & & Suaeda sp. & Acanthus illicifolius & \\
\hline & & Sesuvium portulacastrum & Ipomoea pes-carpae & \\
\hline & & & Sesuvium portulacastrum & \\
\hline $\begin{array}{c}\text { Total } \\
\text { species }\end{array}$ & 2 & 5 & 6 & 1 \\
\hline
\end{tabular}

Edaphic characteristics

Soil characteristics of different selected sites have been presented in table 5. Soil mean temperature was recorded from $29.9-33.5^{\circ} \mathrm{C}$. $\mathrm{pH}$ ranges from 8.37 to 8.68 . Similarly, the values of electrical conductivity were from $4.25 \mathrm{mS} . \mathrm{cm}^{-1}$ to $12.28 \mathrm{mS} . \mathrm{cm}^{-1}$. In this study it was found that more water contents were present in soil at Navsari than Bhavnagar and Surat.

Table 5. Physicochemical characteristics of different mangrove sites.

\begin{tabular}{lccccccccc}
\hline \multirow{2}{*}{ Soil parameters } & \multicolumn{3}{c}{ Navsari } & \multicolumn{3}{c}{ Surat } & \multicolumn{4}{c}{ Bhavnagar } \\
\cline { 2 - 10 } & Mean & SD & SE & Mean & SD & SE & Mean & SD & SE \\
\hline Temperature $\left({ }^{\circ} \mathbf{C}\right)$ & 29.9 & 0.581 & 0.259 & 33.5 & 0.757 & 0.338 & 32.5 & 1.155 & 0.516 \\
pH & 8.376 & 0.034 & 0.015 & 8.680 & 0.147 & 0.066 & 8.396 & 0.096 & 0.043 \\
EC (mS/cm) & 4.248 & 0.190 & 0.085 & 6.626 & 1.755 & 0.785 & 12.282 & 4.228 & 1.891 \\
M.C. (\%) & 60.1 & 3.021 & 1.351 & 23.7 & 6.485 & 2.90 & 44.2 & 0.932 & 0.417 \\
O.Carbon (\%) & 0.17 & 0.02 & 0.01 & 1.09 & 0.07 & 0.04 & 1.52 & 0.04 & 0.02 \\
O.M. (\%) & 0.29 & 0.04 & 0.02 & 1.88 & 0.12 & 0.07 & 2.62 & 0.07 & 0.04 \\
Total Nitrogen (\%) & 2.438 & -- & -- & 1.208 & -- & -- & 4.734 & -- & -- \\
Av. Phosphorous (\%) & 0.019 & 4.73 & 2.73 & 0.011 & 0.58 & 0.33 & 0.022 & 3.61 & 2.08 \\
Sulphate (\%) & 0.081 & 0.012 & 0.007 & 0.111 & 0.003 & 0.002 & 0.119 & 0.001 & 0.001 \\
Cl (ppm) & 12.23 & 0.02 & 0.013 & 18.24 & 0.44 & 0.253 & 38.16 & 1.05 & 0.604 \\
Total Hardness & 265.33 & 2.31 & 1.33 & 538.67 & 4.62 & 2.67 & 1588 & 41.57 & 24.00 \\
(mg CaCO $/ \mathbf{k g})$ & & & & & & & & & \\
\hline
\end{tabular}

Note: SD, Standard deviation; SE, standard error; n, 3; Av., Average.

\section{DISCUSSION}

Gujarat has second largest area of mangroves in India $\left(1058 \mathrm{~km}^{2}\right)$. About $99.4 \%$ mangrove forest area is represented by three mangrove areas; Gulf of Kachchh (15.2\%), Gulf of Khambhat (10.1\%) and Kachchh district including Kori creek (74.1\%) and remaining 0.6\% in Valsad and Navsari district. Even with fewer mangroves area Gulf of Khambhat was reported to have rare mangrove species. The Gulf of Khambhat includes Bharuch, Surat, Navsari and Bhavnagar districts mainly. Therefore coastal area Ghogha from Bhavnagar, Dumas from Surat, Dandi from Navsari, and Dahej from Bharuch has been selected for ecological study. In present study total eight species (Avicennia marina (Forsk.) Vierh, Bruguiera gymnorhiza (L.) Lam., Sonneratia apetala Buch.-Ham., Acanthus ilicifolius, Ipomoea pes-caprae (L.) R.Br., Sesuvium portulacastrum, Salvadora persica and Suaeda sp.) were recorded from Gulf of Khambhat which includes both true mangrove and associate species. Fourteen species of mangrove have already been reported i.e. Avicennia marina (Forsk.) Vierh, Avicennia officinalis L., Avicennia alba Bl., Aegiceras corniculatum (L.) Blanco, Ceriops tagal (Perr.) Robinson, Ceriops decandra (Griff.) Ding Hou, Excoecaria agallocha L., Sonneratia apetala Buch.-Ham., Acanthus ilicifolius L., Bruguiera cylindrica (L.) Bl., Bruguiera gymnorhiza (L.) Savigny, Lumnitzera racemosa Wild, Rhizophora mucronata Lamk., Kandelia candel (L.) Druce (Bhatt et al. 2011). The abundance to frequency ratio indicated that most of the species were contagiously distributed except Sonneratia apetala at two sites (Surat and Navsari), which showed random distribution pattern. Smith (1957), Kershaw (1973), Kumar \& Bhatt (2006) have also reported contagious distribution in natural vegetation. In most of places landward 
mangrove are under pressure due to clearing of mangrove plants for fodder and conversion of mangrove area to other forms of land use (Farnsworth \& Ellison 1997, Ashton \& Macintosh 2002).

Present study revealed that Avicenniaceae is most dominant mangrove family in all selected sites Avicennia marina was the most frequent, most abundant and most dominant species in all selected sites. Average GBH of selected mangrove species ranged from $0.28 \mathrm{~cm}$ to $22 \mathrm{~cm}$. A similar kind of work has also been reported where Avicenniaceae was the dominant mangrove family with $100 \%$ frequency and $72.55 \%$ relative frequency. Average GBH of mangroves was $21.69 \mathrm{~cm}$. Studies also showed that Avicennia marina can withstand more harsh environmental conditions such as high salinity, high temperature etc (Lunar \& Laguardia 2013). It was found that mean height of Avicennia marina was maximum at Navsari $(127.28 \mathrm{~cm})$ followed by Bharuch $(114.6$ $\mathrm{cm})$, Surat $(86.87 \mathrm{~cm})$ and Bhavnagar $(71.68 \mathrm{~cm})$. Among all species the mean height was maximum of Sonneratia apetala $(230.86 \mathrm{~cm})$ followed by Avicennia marina $(127.28 \mathrm{~cm})$ at Navsari site and then by Avicennia marina $(114.6 \mathrm{~cm})$ of Bharuch site and Bruguiera gymnorhiza $(109.82 \mathrm{~cm})$ of Navsari site. In this study it was observed that where plant density is more there plant mean height is less. This may be due to the reason that higher density of Avicennia marina at Bhavnagar may cause reduction in plant growth due to competition for limited resources (Volin et al. 2005, Li et al. 2014).

Soil mean temperature was recorded in the range between $29.9^{\circ} \mathrm{C}$ to $33.5^{\circ} \mathrm{C}$. A similar study has been done where mean temperature of soil was recorded $31.87^{\circ} \mathrm{C}$ at degrading mangrove habitat and $28.26^{\circ} \mathrm{C}$ at luxuriant mangrove habitat (Kathiresan 2002). The $\mathrm{pH}$ was recorded 8.37 (Navsari), 8.39 (Bhavnagar) and 8.68 (Surat) which is supported by study of Rao \& Rao (2014). Study showed that alkaline pH (8.35-8.79) in similar type of habitat. $\mathrm{pH}$ have been reported from 7.11-8.52 in Pondicherry mangroves (Satheeshkumar \& Khan 2009). In present study it was found that more water contents were present in Navsari mangrove soil than Bhavnagar and Surat mangrove soil. The moisture contents (mean values) were $23.7 \%$ (Surat), $44.4 \%$ (Bhavnagar) and $60.1 \%$ (Navsari). High moisture content at Navsari can either be due to freshwater input of Purna river or frequent tidal inundation (Ashton \& Macintosh DJ 2002). It has been observed that $44.4 \%$ moisture content is more suitable for plant density at Bhavnagar site where as on other sites with less and more moisture content plant density was less. Kathiresan (2002) also found moisture content $31.49 \%$ at degrading sites and $42.2 \%$ at luxuriant mangrove habitat. Total nitrogen was recorded from $1.21 \%$ to $4.7 \%$. Similar results were observed by Hossain et al. (2012), where total nitrogen has been reported from $0.057 \%$ to $0.158 \%$ in Sunderban mangrove soil whereas available nitrogen at same site was reported from 0.504 to $2.016 \mu \mathrm{g} . \mathrm{g}^{-1}$. Available nitrogen has been reported from 29.4 to $81.2 \mathrm{ppm}$ (Rao \& Rao 2014). Available phosphorous was found maximum at Bhavnagar $(0.022 \%)$ followed by Navsari $(0.019 \%)$ and Surat $(0.011 \%)$. Available phosphorous of mangrove soil has been reported $3.32 \mathrm{ppm}$ to $5.89 \mathrm{ppm}$ (Rao \& Rao (2014). Phosphates have been reported $0.06 \mathrm{mg} \mathrm{L}^{-1}$ by Dogiparti et al. (2014). The values of organic carbon were observed $0.17 \%$ at Navsari, $1.09 \%$ at Surat and $1.52 \%$ at Bhavnagar site and it has been found that with increase in organic carbon plant density is also increasing. Organic carbon has been reported $4.28 \%$ and 3.12\% at two mangrove areas of Andhra Pradesh (Dogiparti et al. 2014). The organic matter was recorded from $0.29 \%$ to $2.62 \%$, which shows similar results studied by Satheeshkumar \& Khan (2009) where organic matter has been reported from $0.94 \%$ to $3.94 \%$ in mangrove soil.

\section{CONCLUSION}

Present study revealed that Avicenniaceae is only dominant family in the Gulf of Khambhat coastal area, Gujarat and due to anthropogenic disturbance i.e. clear cutting, hydrological changes, oil spills and climate change are creating more pressure on mangrove forests in these sites and the other mangrove species either present in very low number or disappeared from that site. The distribution pattern of mangrove species at Gulf of Khambhat is mostly contagious. Availability of eight species but in less number indicated that in near future the coastal region will be dominated by monotonous species (Avicennia marina). Other species regeneration should be focused while making conservation plans. This study will provide baseline for further study in this area and for development of conservation as well as management strategies for mangrove species.

\section{ACKNOWLEDGMENTS}

We are thankful to UGC for providing non-net fellowship. We extend our thanks to Dean, School of Environment and Sustainable Development, CUG, Gandhinagar, India, for providing all necessary facility. We also thank Dr. Harshad Salvi, Scientist, GEER foundation, Gujarat, India for extending help in identifying the plant species. We would like to thanks my colleagues of the development, Central University of Gujarat. 


\section{REFERENCES}

Alongi DM (2008) Mangrove forests: Resilience, protection from tsunamis, and responses to global climate change, Estuarine. Coastal and Shelf Science 76: 1-13.

APHA (1998) Standard method for examination of water and waste water, $19^{\text {th }}$ edition. American Public Health Association, Washington (Method 2130B).

Ashton EC \& Macintosh DJ (2002) Preliminary assessment of the plant diversity and community ecology of the Sematan mangrove forest, Sarawak, Malaysia. Forest Ecology and Management 166: 111-129.

Bhatt JR, Macintosh DJ, Nayar TS, Pandey CN \& Nilaratna BP (2011) Towards Conservation and Management of Mangrove Ecosystems in India. International Union for Conservation of Nature and Natural Resources, pp. 65-72, 141-153.

Black AL (1973) Soil property changes associated with crop residue management in a wheat- fallow rotation. Soil science Society of America Journal 37: 943-946.

Blasco F, Aizpurum M \& Gers C (2001) Depletion of the mangroves of the Continental Asia. Wetlands Ecology and Management 9: 245-256.

Curtis JT (1959) The Vegetation of Wisconsin. An Ordination of plant communities. University Wisconsin press, Madison Wisconsin, $657 \mathrm{pp}$.

Dogiparti A, Kurapati RK \& Duddu SK (2014) Comparison of Selected Soil Chemical Properties of Two Mangrove Areas of East Coast of Andhra Pradesh South India. International Journal of Innovative Research in Science \& Engineering 2(5): 319-328.

Farnsworth EJ \& Ellison AM (1997) The global conservation status of mangroves. Ambio 26, 328-334.

Hossain MZ, Aziz CB \& Saha ML (2012) Relationship between soil physico-chemical properties and total viable bacterial counts in Sunderban mangrove forests, Bangladesh. Dhaka University Journal of Biological Sciences 21 (2): 169-175.

Kathiresan K (2002) Why are mangroves degrading? Current Science 83(10): 1246-1249.

Kathiresan K (2010) Importance of Mangrove Forests of India. Journal of Coastal Environment 1(1): 11-25.

Kerkhoff (2010) Measuring biodiversity of ecological communities. Ecology Lab 1-3.

Kershaw KA (1973) Quantitative and Dynamic Plant Ecology, $2^{\text {nd }}$ Edition. Elbsd \& Edward Arnold, London, 308 p.

Kumar M \& Bhatt V (2006) Plant Biodiversity and Conservation of Forests in Foot Hills of Garhwal Himalaya. Lyonia 11(2):43-59.

Li F, Xie Y, Liu Y, Tang Y, Chen X, Deng Z, Hu J \& Liu N (2014) Negative influence of burial stress on plant growth was ameliorated by increased plant density in Polygonum hydropiper, Limnologica. Ecology and Management of Inland Waters 45: 33-37.

Lunar BC \& Laguardia MA (2013) Comparative Study of Diversity of Mangroves in Two Conservation Sites of Calatagan, Batangas, Philippines, IAMURE-International Journal of Marine Ecology 1: 1-8.

Rao VVP \& Rao BP (2014) Physico-Chemical Analysis of Mangrove Soil in the Machilipatnam Coastal Region, Krishna District, Andhra Pradesh. International Journal of Engineering Research \& Technology 3(6): 10-12.

Satheeshkumar P \& Khan BA (2009) Seasonal Variations in Physico-Chemical Parameters of Water and Sediment Characteristics of Pondicherry Mangroves. African Journal of Basic \& Applied Sciences 1: 36-43.

Shannon CE \& Wiener W (1963) The Mathematical Theory of Communication. University of Illinois press, Urbana. 117 pp.

Simpson EH (1949) The Measurement of Diversity. Nature 163: 688.

Smith GP (1957) Quantitative Plant Ecology Butterworth. Academic Press, London, 256 pp.

Volin HS, Novoplansky A, Goldberg DE \& Turkington R (2005) Density regulation in annual plant communities under variable resource levels. Oikos 108: 241-252.

Walkey A \& Black IA (1934) An examination of the Degtjareff method for determining soil organic matter and a proposed modification of the chromic soil titration method. Soil Science 37: 30-38.

Whitford PB (1949) Distribution of woodland plants in relation to succession and clonal growth. Ecology 30 : 199-208. 